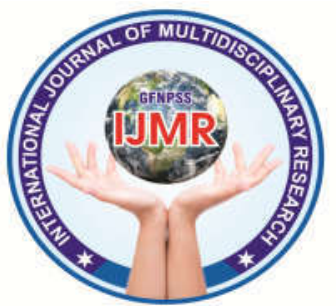

ISSN (0): 2582-693X

Original Article

\title{
EFFECT OF SMOKING ON BLOOD PARAMETERS: COMPARATIVE STUDY BETWEEN PATIENTS HAVING MELANOSIS AND NORMAL MUCOSA
}

\author{
DR. RAVIKUMAR S. KULKARNI, ${ }^{1}$ DR. RAJATH SACHDEVA, ${ }^{2}$ DR. SHOHA H. \\ PATEL ${ }^{3}$ \\ ${ }^{1}$ Professor and Head, Department of Oral Pathology and Microbiology, Daswani Dental \\ College and Research Centre, Kota, Rajasthan, India \\ ${ }^{2,3}$ Post graduate student, Department of Oral Pathology and Microbiology, Daswani Dental \\ College and Research Centre, Kota, Rajasthan, India
}

Corresponding Email: ravioralpathology@gmail.com

\begin{abstract}
Introduction - There are more than one billion smokers in the world with an increased habit of smoking worldwide more than three million people currently die each year from smoking. Young people are smoking earlier and more heavily.

Material and methods_ The study was carried out in the Postgraduate Department of Oral Pathology and microbiology, Daswani Dental College and Research Centre, Kota. Patients with potentially malignant oral lesions (PMOD) with history of tobacco habit for a minimum of consecutive 5 years and patients with history of tobacco habit for a minimum of consecutive 5 years but without any potentially malignant oral lesions(PMOD) were selected for the study. Total $100(50+50)$ subjects were selected.

Results:Comparing the mean total cholesterol of two groups, $t$ test showed significantly different and lower (15.4\%) TC in Group II as compared to Group I (172.41 \pm 4.86 vs. $145.80 \pm 2.36, \mathrm{t}=4.92, \mathrm{p}<0.001)$.

Conclusion - Prospective studies on a large sample of tobacco abusers followed up for a long duration will help in proving or disproving the role of metabolic derangement in oral carcinogenesis.
\end{abstract}

Keywords :Smoking, total cholesterol, high density lipoprotein, low density lipoprotein, very low density lipoprotein, HbA1c, blood glucose.

\section{INTRODUCTION}

There are more than one billion smokers in the world with an increased habit of smoking worldwide more than three million people currently die each year from smoking. In a study by World 


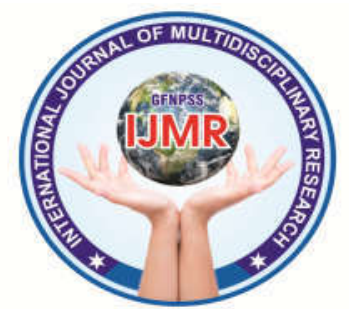

Health Organization, the gender were selected for the study. Total 100 empowerment measure has been shown to be positively and significantly correlated to gender smoking ratio. About one billion men and 250 million women are daily smokers worldwide. But in India, tobacco consumption continues to rise, even though the evidence mount regarding its hazards. Young people are smoking earlier and more heavily.

\section{AIMS AND OBJECTIVES}

- To assess the association between anemia, hyperglycemia, and hyperlipidemia with development of potentially malignant oral lesions in tobacco users.

- Hence compare serum parameters between the tobacco users with PMOD and tobacco users without PMOD.

\section{MATERIAL AND METHODS}

The study was carried out in the Postgraduate Department of Oral Pathology and microbiology, Daswani Dental College and Research Centre, Kota, Rajasthan. Patients with potentially malignant oral lesions (PMOD) with history of tobacco habit for a minimum of consecutive 5 years and patients with history of tobacco habit for a minimum of consecutive 5 years but without any potentially malignant oral lesions (PMOD) $(50+50)$ subjects were selected. Patients diagnosed with any other systemic disorders except hyperlipidemia, hyperglycemia, and iron deficiency anemia were excluded from the study.

$4 \mathrm{ml}$ of venous blood was withdrawn from antecuboital fossa of left arm under asceptic condition. Sample taken was immediately transferred into a glass vial containing EDTA. Serum Hemoglobin, Serum Lipid Profile, Serum Glycosylated Hemoglobin was assessed using the following methods. The results obtained was compared and correlated statistically to assess the possible association between selected serum markers and PMODs.

Data were summarized as Mean \pm SE (standard error of the mean). Groups were compared by independent Student's t test. Categorical (discrete) groups were compared by chi-square $\left(\chi^{2}\right)$ test. A twotailed $(\alpha=2) \quad p$ value less than 0.05 $(p<0.05)$ was considered statistically significant. Analyses were performed on SPSS (windows version 17.0).

\section{OBSERVATIONS AND RESULTS}

The present study compares the selected blood parameters among tobacco users with and without potentially 


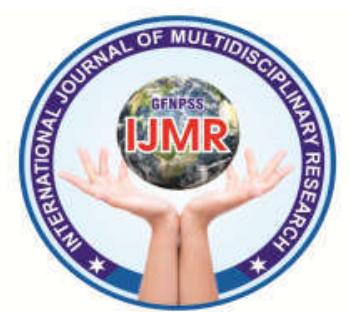

subjects were recruited, 50 tobacco users without potentially malignant oral disorders (Group I) and 50 tobacco users with potentially malignant oral disorders (Group II). The outcome measures of the study were TC, HDLC, LDL, VLDL, TG, HbA1c, MBG and $\mathrm{Hb}$. All blood parameters were measured in $\mathrm{mg} / \mathrm{dl}$ except HbAlc which is measured in \%. The objective of the study was to compare the blood parameters between the two groups (Group I and Group II).

\section{DEMOGRAPHIC}

\section{CHARACTERISTICS}

The demographic characteristics of two groups are summarized in Table 1. The age of Group I and Group II ranged from 17 to $70 \mathrm{yrs}$ and 19 to $72 \mathrm{yrs}$ respectively with mean $( \pm$ SE) $36.60 \pm$ 1.65 yrs and $38.98 \pm 1.42$ yrs respectively and median 35 yrs and 40 yrs respectively. Further, in both groups, there were 11 $(22.0 \%)$ females and $39(78.0 \%)$ males and thus the sex proportion $(\mathrm{F} / \mathrm{M})$ was also similar between the two groups $\left(\chi^{2}=0.00\right.$, $\mathrm{p}=1.000)$.

Similarly, the type of habit $\left(\chi^{2}=4.38, p=0.223\right)$ and duration of habit $\left(\chi^{2}=1.98, \quad \mathrm{p}=0.159\right) \quad$ also not differed between the two groups i.e. found to be statically the same. In other words, subjects of two groups were demographically matched and comparable and thus may also not influence the study outcome measures (i.e. blood parameter levels).

Table 1: Demographic characteristics of two groups

\begin{tabular}{|c|c|c|c|c|}
\hline $\begin{array}{l}\text { Demographic } \\
\text { Characteristics }\end{array}$ & $\begin{array}{l}\text { Group } \\
(n=50)\end{array}$ & $\begin{array}{l}\text { Group II } \\
(n=50)\end{array}$ & $\begin{array}{l}\text { t/ } \chi^{2} \\
\text { value }\end{array}$ & $\begin{array}{l}\text { p } \\
\text { value }\end{array}$ \\
\hline $\begin{array}{l}\text { Age (yrs): } \\
\text { Mean } \pm \text { SE }\end{array}$ & $36.60 \pm 1.65$ & $\begin{array}{ll}38.98 \quad \pm \\
1.42 & \end{array}$ & 1.09 & 0.277 \\
\hline $\begin{array}{l}\text { Sex: } \\
\quad \text { Female } \\
\text { Male }\end{array}$ & $\begin{array}{l}11(22.0) \\
39(78.0)\end{array}$ & $\begin{array}{l}11(22.0) \\
39(78.0)\end{array}$ & 0.00 & 1.000 \\
\hline $\begin{array}{l}\text { Type of habit: } \\
\text { Tobacco chewer } \\
\text { Tobacco chewer \& } \\
\text { smoker } \\
\text { Tobacco chewer \& } \\
\text { alcohol } \\
\text { Tobacco chewer, smoker } \\
\text { \& alcohol } \\
\end{array}$ & $\begin{array}{l}30(60.0) \\
10(20.0) \\
8(16.0) \\
2(4.0)\end{array}$ & $\begin{array}{l}24(48.0) \\
9(18.0) \\
9(18.0) \\
8(16.0\end{array}$ & 4.38 & 0.223 \\
\hline $\begin{array}{l}\text { Duration of habit (yrs): } \\
\leq 10 \\
>10\end{array}$ & $\begin{array}{l}26(52.0) \\
24(48.0)\end{array}$ & $\begin{array}{l}19(38.0) \\
31(62.0)\end{array}$ & 1.98 & 0.159 \\
\hline $\begin{array}{l}\text { Demographic } \\
\text { characteristics }\end{array}$ & $\begin{array}{l}\text { Group I } \\
(n=50)\end{array}$ & $\begin{array}{l}\text { Group II } \\
(n=50)\end{array}$ & $\begin{array}{l}\text { t/ } \chi^{2} \\
\text { value }\end{array}$ & $\begin{array}{l}\text { p } \\
\text { value }\end{array}$ \\
\hline $\begin{array}{l}\text { Age (yrs): } \\
\text { Mean } \pm \text { SE }\end{array}$ & $36.60 \pm 1.65$ & $\begin{array}{ll}38.98 \quad \pm \\
1.42 & \end{array}$ & 1.09 & 0.277 \\
\hline $\begin{array}{l}\text { Sex: } \\
\text { Female } \\
\text { Male }\end{array}$ & $\begin{array}{l}11(22.0) \\
39(78.0)\end{array}$ & $\begin{array}{l}11(22.0) \\
39(78.0)\end{array}$ & 0.00 & 1.000 \\
\hline $\begin{array}{l}\text { Type of habit: } \\
\text { Tobacco chewer } \\
\text { Tobacco chewer \& } \\
\text { smoker } \\
\text { Tobacco chewer \& } \\
\text { alcohol Tobacco chewer, } \\
\text { smoker \& alcohol }\end{array}$ & $\begin{array}{l}30(60.0) \\
10(20.0) \\
8(16.0) \\
2(4.0)\end{array}$ & $\begin{array}{l}24(48.0) \\
9(18.0) \\
9(18.0) \\
8(16.0)\end{array}$ & 4.38 & 0.223 \\
\hline $\begin{array}{l}\text { Duration of habit (yrs): } \\
\quad \leq 10 \\
>10\end{array}$ & $\begin{array}{l}26(52.0) \\
24(48.0)\end{array}$ & $\begin{array}{l}19(38.0) \\
31(62.0)\end{array}$ & 1.98 & 0.159 \\
\hline
\end{tabular}




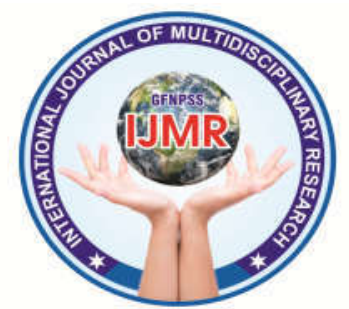

Table 1: Demographic characteristics of two groups

\section{Outcome measures}

\section{Total Cholesterol (TC)}

The TC of two groups is summarized in Table 2. The TC of Group I and Group II ranged from 102.5 to $240.0 \mathrm{mg} / \mathrm{dl}$ and 82.0 to $193.0 \mathrm{mg} / \mathrm{dl}$ with mean $( \pm \mathrm{SE}) 172.41 \pm$ $4.86 \mathrm{mg} / \mathrm{dl}$ and $145.80 \pm 2.36 \mathrm{mg} / \mathrm{dl}$ respectively and median $171 \mathrm{mg} / \mathrm{dl}$ and $144 \mathrm{mg} / \mathrm{dl}$ respectively. The mean TC lowered comparatively in Group II as compared to Group I. Comparing the mean TC of two groups, $t$ test showed significantly different and lower (15.4\%) TC in Group II as compared to Group I $(172.41 \pm 4.86$ vs. $145.80 \pm 2.36, \mathrm{t}=4.92$, $\mathrm{p}<0.001)$.

Table 2: TC (Mean \pm SE) of two groups

\begin{tabular}{|l|l|l|l|}
\hline $\begin{array}{l}\text { Group I } \\
(\mathbf{n}=\mathbf{5 0})\end{array}$ & $\begin{array}{l}\text { Group II } \\
(\mathbf{n}=\mathbf{5 0})\end{array}$ & $\begin{array}{l}\mathbf{\text { }} \\
\text { value }\end{array}$ & \begin{tabular}{l} 
value \\
\hline $172.41 \pm 4.86$
\end{tabular} \\
$\begin{array}{l}145.80 \pm 2.36 \\
(102.5 \text { to } 240.0)\end{array}$ & 4.92 & $<0.001$ \\
$(82.0$ to 193.0$)$ & & \\
\hline
\end{tabular}

Numbers in parenthesis indicates the range (min to max)

\section{High Density Lipoprotein Cholesterol (HDLC)}

The HDLC of two groups is summarized in Table 3. The HDLC of Group I and Group II ranged from 34.2 to $70.0 \mathrm{mg} / \mathrm{dl}$ and 21.8 to $64.3 \mathrm{mg} / \mathrm{dl}$ with mean $( \pm \mathrm{SE}) 53.99 \pm 1.34 \mathrm{mg} / \mathrm{dl}$ and 45.06 $\pm 1.20 \mathrm{mg} / \mathrm{dl}$ respectively and median 54 $\mathrm{mg} / \mathrm{dl}$ and $47 \mathrm{mg} / \mathrm{dl}$ respectively. The mean HDLC lowered comparatively in Group II as compared to Group I. Comparing the mean HDLC of two groups, $t$ test showed significantly different and lower (16.6\%) HDLC in Group II as compared to Group I (53.99 \pm 1.34 vs. $45.06 \pm 1.20, \mathrm{t}=4.97, \mathrm{p}<0.001)$.

Table 3: HDLC (Mean \pm SE) of two groups

\begin{tabular}{|l|l|l|l|}
\hline $\begin{array}{l}\text { Group I } \\
(\mathbf{n}=\mathbf{5 0})\end{array}$ & $\begin{array}{l}\text { Group II } \\
(\mathbf{n}=\mathbf{5 0})\end{array}$ & $\begin{array}{l}\text { t } \\
\text { value }\end{array}$ & $\begin{array}{l}\text { p } \\
\text { value }\end{array}$ \\
\hline $\begin{array}{l}53.99 \pm 1.34 \\
(34.2 \text { to } 70.0)\end{array}$ & $\begin{array}{l}45.06 \pm 1.20 \\
(21.8 \text { to } 64.3)\end{array}$ & 4.97 & $<0.001$ \\
\hline
\end{tabular}

Numbers in parenthesis indicates the range (min to max)

\section{Low Density Lipoprotein Cholesterol (LDL)}

The LDL of two groups is summarized in Table 4. The LDL of Group I and Group II ranged from 29.1 to $121.7 \mathrm{mg} / \mathrm{dl}$ and 30.4 to $106.1 \mathrm{mg} / \mathrm{dl}$ with mean $( \pm \mathrm{SE}) 86.07 \pm 2.94 \mathrm{mg} / \mathrm{dl}$ and $76.86 \pm 1.67 \mathrm{mg} / \mathrm{dl}$ respectively and median $84 \mathrm{mg} / \mathrm{dl}$ and $78 \mathrm{mg} / \mathrm{dl}$ respectively. The mean LDL lowered comparatively in Group II as compared to Group I. Comparing the mean LDL 


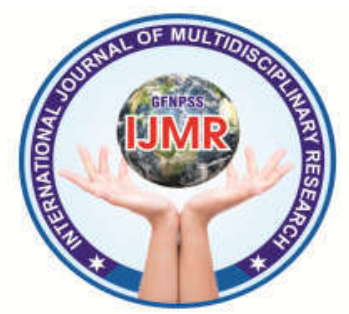

of two groups, $t$ test showed significantly different and lower $(10.7 \%)$ LDL in Group II as compared to Group I $(86.07 \pm 2.94$ vs. $76.86 \pm$ $1.67, \mathrm{t}=2.72, \mathrm{p}=0.008)$.

Table 4: LDL (Mean \pm SE) of two groups

\begin{tabular}{|l|l|l|l|}
\hline $\begin{array}{l}\text { Group I } \\
(\mathbf{n = 5 0 )}\end{array}$ & $\begin{array}{l}\text { Group II } \\
(\mathbf{n = 5 0 )}\end{array}$ & $\mathbf{t}$ & $\mathbf{p}$ \\
\hline $86.07 \pm 2.94$ & $76.86 \pm 1.67$ & 2.72 & 0.008 \\
$(29.1$ to & $(30.4 \quad$ to & & \\
$121.7)$ & $106.1)$ & & \\
\hline
\end{tabular}

Numbers in parenthesis indicates the range (min to max)

\section{Very Low Density Lipoprotein Cholesterol}

The VLDL of two groups is summarized in Table 5. The VLDL of Group I and Group II ranged from 17.8 to $52.7 \mathrm{mg} / \mathrm{dl}$ and 6.1 to $45.0 \mathrm{mg} / \mathrm{dl}$ with mean $( \pm \mathrm{SE}) 32.79 \pm 1.49 \mathrm{mg} / \mathrm{dl}$ and 23.63 $\pm 0.92 \mathrm{mg} / \mathrm{dl}$ respectively and median 31 $\mathrm{mg} / \mathrm{dl}$ and $23 \mathrm{mg} / \mathrm{dl}$ respectively. The mean VLDL lowered comparatively in Group II as compared to Group I. Comparing the mean VLDL of two groups, $\mathrm{t}$ test showed significantly different and lower (27.9\%) VLDL in Group II as compared to Group I (32.79 \pm 1.49 vs. $23.63 \pm 0.92, \mathrm{t}=5.23, \mathrm{p}<0.001)$.
Table 5: VLDL (Mean \pm SE) of two groups

\begin{tabular}{|l|l|l|l|}
\hline $\begin{array}{l}\text { Group I } \\
(\mathbf{n}=\mathbf{5 0})\end{array}$ & $\begin{array}{l}\text { Group II } \\
(\mathbf{n}=\mathbf{5 0})\end{array}$ & $\begin{array}{l}\text { t } \\
\text { value }\end{array}$ & $\begin{array}{l}\mathbf{p} \\
\text { value }\end{array}$ \\
\hline $32.79 \pm 1.49$ & $23.63 \pm 0.92$ & 5.23 & $<0.001$ \\
$(17.8$ to 52.7$)$ & $(6.1$ to 45.0$)$ & & \\
\hline
\end{tabular}

Numbers in parenthesis indicates the range (min to max)

\section{Total TriGlycerides}

The TG of two groups is summarized in Table 6 and also shown in Graph. 9. The TG of Group I and Group II ranged from 89.0 to $263.6 \mathrm{mg} / \mathrm{dl}$ and 30.3 to $225.0 \mathrm{mg} / \mathrm{dl}$ with mean ( \pm SE) $163.94 \pm$ $7.45 \mathrm{mg} / \mathrm{dl}$ and $118.15 \pm 4.60 \mathrm{mg} / \mathrm{dl}$ respectively and median $157 \mathrm{mg} / \mathrm{dl}$ and $114 \mathrm{mg} / \mathrm{dl}$ respectively. The mean TG lowered comparatively in Group II as compared to Group I. Comparing the mean TG of two groups, $t$ test showed significantly different and lower (27.9\%) TG in Group II as compared to Group I $(163.94 \pm 7.45$ vs. $118.15 \pm 4.60, \mathrm{t}=5.23$, $\mathrm{p}<0.001)$.

Table 6: TG (Mean \pm SE) of two groups

\begin{tabular}{|l|l|l|l|}
\hline $\begin{array}{l}\text { Group I } \\
(\mathbf{n}=50)\end{array}$ & Group II & $\mathbf{t}$ & $\mathbf{p}$ \\
$(\mathbf{n}=\mathbf{5 0})$ & value & value \\
\hline $163.94 \pm 7.45$ & $118.15 \pm 4.60$ & 5.23 & $<0.001$ \\
$(89.0 \quad$ to & $(30.3 \quad$ to & & \\
$263.6)$ & $225.0)$ & & \\
\hline
\end{tabular}

Numbers in parenthesis indicates the range (min to max) 


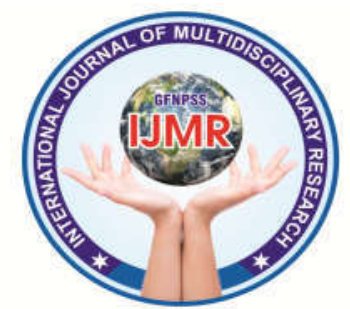

VI. Hemoglobin A1c (HbA1c)

The HbA1c of two groups is summarized in Table 7. The HbAlc of Group I and Group II ranged from 4.2 to $6.3 \%$ and 4.2 to $6.5 \%$ with mean $( \pm \mathrm{SE})$ $5.46 \pm 0.07 \%$ and $5.27 \pm 0.07 \%$ respectively and median $6 \%$ and $5 \%$ respectively. The mean $\mathrm{HbAlc}$ lowered slightly in Group II as compared to Group I. Comparing the mean HbAlc of two groups, $\mathrm{t}$ test showed similar $\mathrm{HbAlc}$ between two groups $(5.46 \pm 0.07$ vs. 5.27 $\pm 0.07, \mathrm{t}=1.83, \mathrm{p}=0.070$ ) though it lower $3.5 \%$ in Group II as compared to Group I.

Table 7: HbA1c (Mean \pm SE) of two groups

\begin{tabular}{|l|l|l|l|}
\hline $\begin{array}{l}\text { Group I } \\
(\mathbf{n}=\mathbf{5 0})\end{array}$ & $\begin{array}{l}\text { Group II } \\
(\mathbf{n = 5 0})\end{array}$ & $\begin{array}{l}\mathbf{t} \\
\text { value }\end{array}$ & $\begin{array}{l}\mathbf{p} \\
\text { value }\end{array}$ \\
\hline $5.46 \pm 0.07$ & $5.27 \pm 0.07$ & 1.83 & 0.070 \\
$(4.2$ to 6.3$)$ & $(4.2$ to 6.5$)$ & & \\
\hline
\end{tabular}

\section{Mean Blood Glucose (MBG)}

The MBG of two groups is summarized in Table 8. The MBG of Group I and Group II ranged from 43.0 to $128.0 \mathrm{mg} / \mathrm{dl}$ and 43.0 to $138.0 \mathrm{mg} / \mathrm{dl}$ with mean $( \pm \mathrm{SE}) 88.82 \pm 3.19 \mathrm{mg} / \mathrm{dl}$ and 80.30 $\pm 3.40 \mathrm{mg} / \mathrm{dl}$ respectively and median 94 $\mathrm{mg} / \mathrm{dl}$ and $76 \mathrm{mg} / \mathrm{dl}$ respectively. The mean MBG lowered slightly in Group II as compared to Group I. Comparing the mean MBG of two groups, $t$ test showed similar MBG between two groups $(88.82 \pm 3.19$ vs. $80.30 \pm 3.40, \mathrm{t}=1.83, \mathrm{p}=0.071)$ though it lower $9.6 \%$ in Group II as compared to Group I.

Table 8: MBG (Mean \pm SE) of two groups

\begin{tabular}{|l|l|l|l|}
\hline $\begin{array}{l}\text { Group I } \\
(\mathbf{n}=50)\end{array}$ & $\begin{array}{l}\text { Group II } \\
(\mathbf{n}=50)\end{array}$ & $\mathbf{t}$ & $\mathbf{p}$ \\
& value & value \\
\hline $88.82 \pm 3.19$ & $80.30 \pm 3.40$ & 1.83 & 0.071 \\
$(43.0$ to 128.0$)$ & $\begin{array}{l}(43.0 \quad \text { to } \\
138.0)\end{array}$ & & \\
& & & \\
\hline
\end{tabular}

Numbers in parenthesis indicates the range (min to max)

\section{Hb}

The $\mathrm{Hb}$ of two groups is summarized in Table 9. The Hb of Group I and Group II ranged from 10.4 to 14.0 $\mathrm{mg} / \mathrm{dl}$ and 10.6 to $14.4 \mathrm{mg} / \mathrm{dl}$ with mean $( \pm$ SE) $12.93 \pm 0.12 \mathrm{mg} / \mathrm{dl}$ and $12.61 \pm 0.11$ $\mathrm{mg} / \mathrm{dl}$ respectively and median $13 \mathrm{mg} / \mathrm{dl}$ and $13 \mathrm{mg} / \mathrm{dl}$ respectively. The mean $\mathrm{Hb}$ lowered slightly in Group II as compared to Group I. Comparing the mean $\mathrm{HB}$ of two groups, $\mathrm{t}$ test showed similar $\mathrm{Hb}$ between two groups $(12.93 \pm 0.12$ vs. $12.61 \pm 0.11, \mathrm{t}=1.95, \mathrm{p}=0.054)$ though it lower $2.5 \%$ in Group II as compared to Group I. 


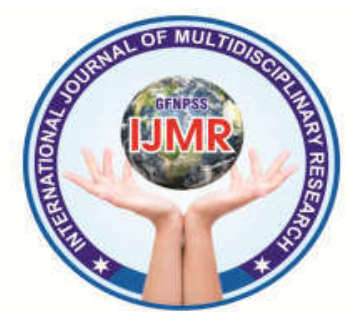

Table 9: Hb (Mean \pm SE) of two groups

\begin{tabular}{|l|l|l|l|}
\hline $\begin{array}{l}\text { Group I } \\
(\mathbf{n = 5 0 )}\end{array}$ & Group II & $\mathbf{t}$ & $\mathbf{p}$ \\
$(\mathbf{n = 5 0})$ & value & value \\
\hline $12.93 \pm 0.12$ & $12.61 \pm 0.11$ & 1.95 & 0.054 \\
$(10.4 \quad$ to & $(10.6 \quad$ to & & \\
$14.0)$ & $14.4)$ & & \\
\hline
\end{tabular}

Numbers in parenthesis indicates the range (min to $\max )$

\section{DISCUSSION}

The present study was undertaken in Daswani dental college and research centre, Kota, Rajasthan. It compares selected blood parameters among tobacco users with and without potentially malignant oral disorders. A total of 100 subjects were recruited, 50 tobacco users without potentially malignant oral disorders (Group I) and 50 tobacco users with potentially malignant oral disorders (Group II). The outcome measures of the study were TC, HDLC, LDL, VLDL, TG, HbAlc, MBG and Hb. All blood parameters were measured in $\mathrm{mg} / \mathrm{dl}$ except HbAlc which is measured in \%. The objective of the study was to compare the blood parameters between the two groups (Group I and Group II).

The results of the study showed that mean Total Cholesterol (TC), mean High Density Lipoprotein Cholesterol (HDLC), mean Low Density Lipoprotein Cholesterol (LDL), mean Very Low Density Lipoprotein Cholesterol (VLDL) and mean Total Triglycerides (TG) were significantly lowered $(p<0.001)$ in Group II (tobacco users with potentially malignant oral disorders) as compared to Group I (tobacco users without potentially malignant oral disorders). There was also a slight decrease in the mean Hemoglobin A1c (HbA1c) and mean blood glucose (MBG) in Group II but these differences were statistically not significant $(\mathrm{p}=0.070)$ and $(\mathrm{p}=0.071)$. Similarly the mean Hemoglobin $(\mathrm{Hb})$ was slightly lowered in Group II as compared to Group I but the difference was not statistically significant $(\mathrm{p}=0.054)$.

In the present study the values evidently show that Precancer and Oral Cancer patients have lower serum cholesterol, significantly lower serum HDL cholesterol and lower serum triglyceride values when compared with healthy control groups. These results are consistent with the result of studies by Lohe et al in 2010 who found that significant decrease in TC, HDL, VLDL, and triglyceride in Oral Cancer group; and significant decrease in TC, and HDL in 


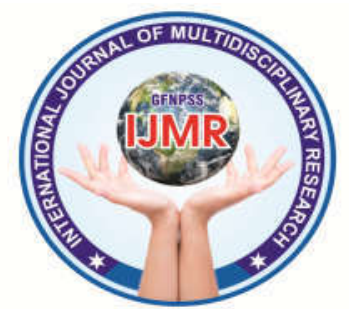

Oral precancer group as compared to significantly lower serum cholesterol, Control[1]

Gaurav Ghosh et al in 2011 also lower serum HDL cholesterol and lower serum triglyceride values when compared with healthy control groups. This result is consistent with the study of Syeda Arshiya Ara et al. in 2013 who had reported the parameters of lipid profile for the OSMF group showed a significant decrease when compared to normal subjects. She reported that Excessive use of areca nut may also induce the production of free radicals and reactive oxygen species, which are responsible for high rate of oxidation/ peroxidation of polyunsaturated fatty acids which affect essential constituents of cell membrane and might be involved in tumorogenesis [7].

Ravi Mehrotra et al. in 2009 observed that a significant decrease in plasma total cholesterol, HDLC and ApoA1 in patients with OSMF as compared to the controls. Thus an inverse relationship between plasma lipid levels and patients was found in OSMF [8]. Results were also consistent with the study of Altaf Hussain Chalkoo et al in 2011. They reported a significant decrease in Serum cholesterol and LDLC whereas serum triglycerides and HDLC were slightly increased in some

In the present study the values evidently show that OMSF patients have 


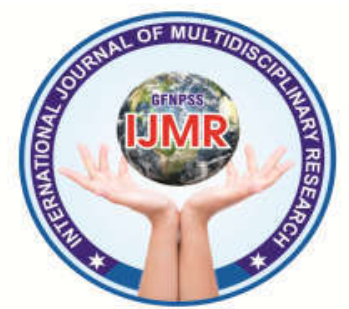

strengthens the evidence of alterations in plasma lipid levels in OSMF patients [9] Result was also consistent with the study of Pramod kumar et al. in 2013. They found that a statistically significant decrease in plasma total cholesterol, LDL and HDL was observed in patients with OSMF as compared to the controls[10]. Result was also consistent with the study of Gopal Sharma et al. in 2013. They found a significant decrease in serum cholesterol, LDLC and LDLC/HDLC ratio in OSMF patients [11].

This may be due to tobacco carcinogenesis which induce generation of free radicals and reactive species, which are responsible for high rate of oxidation / peroxidation of polyunsaturated fatty acids. Another hypothesis says that hypolipidemia is a result of direct lipid lowering effect of tumor cells as these neoplastic cells directly utilize cholesterol for their own metabolism, thus it can be stated that the lower serum lipid status may be a useful indicator i.e, biochemical marker for initial changes occurring in neoplastic cells [12].

Only few research studies have been done on diabetes and oral cancer. The molecular mechanisms associated with diabetes and cancer development are still not clear. The association between diabetes and oral cancers may be due to shared risk factors between the two diseases, such as diet, aging, obesity and physical inactivity. However, the etiologic factors of oral cancer such as tobacco, alcohol can also contribute to oral cancer in diabetic patients. Hyperglycemia generates oxidative stress that damages the DNA and induces carcinogenesis. Hyperinsulinemia is the characteristic feature of diabetes Type II patients. Insulin activates the structurally similar insulinlike receptor that increases the risk of cancer. Hyperinsulinemia causes unregulated insulin receptor signaling that increases cancer risk by its proliferative and antiapoptotic effects. It also causes increased mitogenic activity of insulin post-receptor molecular mechanisms like intracellular up-regulation of the insulin mitogenic pathway and insulin residence time on the receptor. A few studies on oral cancer and diabetes have shown an association between them while a few studies have indicated the opposite [13].

In our study, the mean Haemoglobin A1c ( $\mathrm{HbAlc}$ ) and mean blood glucose (MBG) of two groups showed similar findings between the two groups though it was lower $3.5 \%$ ( 


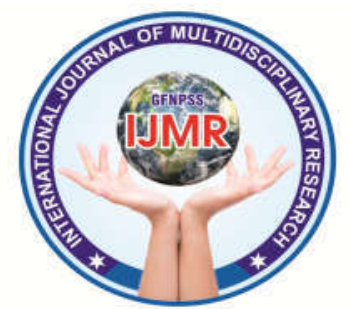

$p=0.070)$ and $9.6 \%(p=0.071)$ respectively

in Group II (tobacco users with potentially malignant oral disorders)as compared to Group I(tobacco users without potentially malignant oral disorders).

These findings were similar to a study by Mohsin et al in 2014 [14] revealing no significant association between premalignant lesions and diabetic patients in their study. Muralidara et al in 2013. also did not find any association between precancerous lesions and serum glucose levels. [15]

However, there are studies, which support an increase in cancer risk and mortality in diabetic patients. In the study done by Thomas et al in 2004, analyzing the risk factors of leukoplakia, he found that diabetic patients are three times more associated with leukoplakia than nondiabetic patients. They attributed this increased incidence of leukoplakia in diabetics to the metabolic and immunologic changes in the oral mucosa.[16]

Dikshit et al. in 2006 also found higher incidence of leukoplakia and lichen planus in diabetic patients in comparison with non-diabetic patients.[17]

A study was done by Ujpál $\boldsymbol{e t} \boldsymbol{a l}$. in 2004 reveals $25.6 \%$ of Type $I$ and
$31.3 \%$ of Type II diabetic patients had glossitis and chronic cheilitis that are considered to be precursors of malignant transformations. $10.9 \%$ of Type I and $16.9 \%$ of Type II had benign tumors. 3.2\% of Type I and $11 \%$ of Type II had leukoplakia or erythroplakia. There was higher incidence of gingival cancer (29\%) and lip cancer $(24 \%)$ in diabetics as compared to the non-diabetic group [18].

According to Weinberg, research and clinical observations during the past six decades have shown that: 1. Iron promotes cancer cell growth; 2. Hosts attempt to withhold or withdraw iron from cancer cells; and 3. Iron is a factor in prevention and in therapy of neoplastic disease. Thus deficient or excess intake of iron could have contributed to the carcinogenesis, habits could have altered iron intake as well as its metabolism and influenced tumorigenesis, and presence of the malignancy itself could have altered iron homeostasis [19].

However, in the present study, the mean Hemoglobin $(\mathrm{Hb})$ was only slightly lowered $2.5 \% \quad(p=0.054)$ in Group II (tobacco users with potentially malignant oral disorders) as compared to Group I (tobacco users without potentially malignant oral disorders), showing no 


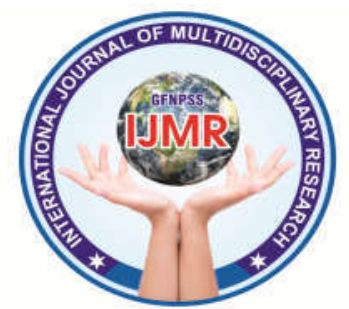

significance of the role of iron in disease. They attributed the decrease in precancer and cancer carcinogenesis. iron to utilization for collagen synthesis Various mechanisms for the induction of malignancy and [22]

According to Maguire (1982), premalignancy due to iron deficiency has been propounded. According to Rajendran et al., submucous fibrosis appears to be an altered oral mucosa following prolonged period of chronic deficiency of iron and/or vitamin "B" complex especially folic acid, with hypersensitivity caused by local irritants and the resultant persistent juxta epithelial inflammatory response act as the initiating factor leading to a defective inflammatoryreparative response, culminating in fibrotic healing. A case control study on patients with precancerous diseases showed that serum iron was significantly depressed in such patients [20]

Jayadeep et al in 1997 reported that oral cancer patients have significantly lesser serum iron in oral cancer patients compared to those with normal controls and those with oral leukoplakias.[21]

Anuradha et al in 1993 observed that in patients with submucous fibrosis (all of whom were heavy tobacco and arecanut users too) serum iron decreased whereas the total tissue collagen content increased significantly in patients with advanced 


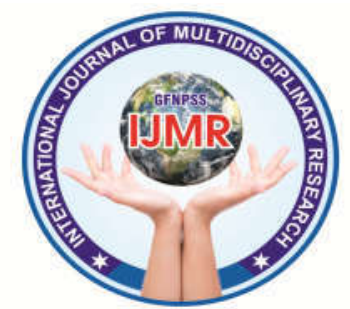

would be ideal for studying the effect of these parameters on PMODs and oral cancer. Another drawback includes the heterogeneity of PMODs included in our study group. Disorders like leukoplakia and OSMF have different pathogenic pathways and hence may be associated with different systemic factors. Hence a stricter categorization of these lesions would give a clearer picture of the association of these metabolic parameters with different PMODs.

To conclude, the results of the present study indicate that a decreased serum lipid profile could be associated with higher risk of development of PMODs in tobacco abusers which in turn may predispose this group for development of oral cancer thus suggesting some role of lipid metabolism pathway in oral cancer. Although not statistically significant but a decrease in hemoglobin levels were also found to be associated with development of PMODs in this study. On the other hand the results of this study failed to demonstrate any relationship between serum glycemic status and development of PMODs. Prospective studies on a large sample of tobacco abusers followed up for a long duration will help in proving or disproving the role of metabolic derangement in oral carcinogenesis.

\section{REFERENCES}

1. Lohe Vidya K. et al. Evaluation of correlation of serum lipid profile in patients with oral cancer and precancer and its association with tobacco abuse. J Oral Pathol Med 2010; 39: 141-148.

2. Ghosh Gaurav et al. Alteration in serum lipid profile pattern in oral squamous cell carcinoma patients. J C Dent Prac 2011; 12(6): 451-456.

3. Patel P.S et al. Alteration in plasma lipid profile pattern in head and neck cancer and oral precancerous conditions. Ind J. Cancer 2004; 41: 25 31.

4. Gupta Shally et al. Alteration in serum lipid profile patterns in oral cancer and oral precancerous lesion and condition - A clinical study. Ind. J. Dent 2011; 2 (2): 1-7.

5. Pathan A B et al. Plasma lipid profile as predictor of cancer. Int. J Rev. life. Sci 2012; 2(2): 53-57.

6. Jyoti G Chawda et al. The relationship between serum lipid level and the risk of oral cancer. I J Med. Ped. Oncol; 32(1): 34-37.

7. Ara Syeda Arshiya et al. Correlation of serum lipid profile in patients with oral 


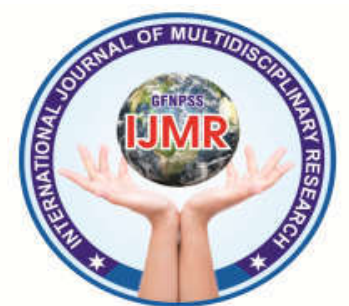

submucous fibrosis in Gulbarga. Int $\mathbf{J}$ dent clin 2013; 5(2).

8. Mehrotra Ravi et al. Lipid profile in oral submucous www. Lipid world.com/ content/8/1/29 2009, 8:29

9. Chalkoo Altaf Hussain et al. A Study on Alterations in Plasma Lipid Profile Patterns in OSMF Patients. J Ind Acad Oral Med Rad 2011;23(1):36-38.

10. Kumar $\mathrm{P}$ et al. Alteration in plasma lipid profile in oral submucous fibrosis patients: A case control study. South Asian J Cancer 2013;2:147-9.

11. Sharma Gopal et al. Lipid Profile in Oral Submucous Fibrosis Patients in India -A Pilot Study. I J B A Med Res 2013; 7(2): 790-796.

12. Kumar Priya et al. Serum lipid profile in oral cancer and leukoplakia: Correlation with tobacco abuse and histological grading. J Can Res Ther 2012; 8:384-8. 1-7.

13. Noto H, Goto A, Tsujimoto T, Osame K, Noda M. Latest insights into the risk of cancer in diabetes. $\mathrm{J}$ Diabetes Investig 2013;4:225-32.

14. Mohsin SF, Ahmed SA, Fawwad A, Basit A. Prevalence of oral mucosal alterations in type 2 diabetes mellitus patients attending a diabetic center. Pak J Med Sci 2014;30:716-9.
15. Yadiyal M, Shenoy N, Shenoy A, Ahmed J. Are diabetics victims of oral cancer? Int J Bioassays 2013;2:904-6.

16. Dietrich T, Reichart PA, Scheifele C. Clinical risk factors of oral leukoplakia in a representative sample of the US population. Oral Oncol 2004;40:15863.

17. Dikshit RP, Ramadas K, Hashibe M, Thomas G, Somanathan T, Sankaranarayanan R. Association between diabetes mellitus and premalignant oral diseases: A cross sectional study in Kerala, India. Int J Cancer 2006;118:453-7.

18. Ujpál M, Matos O, Bíbok G, SomogyiA, Szabó G, Suba Z. Diabetes and oral tumors in Hungary:Epidemiological correlati onns. Diabetes Care 2004;27:770-4. cancer in diabetes. J Diabetes Investig 2013;4:225-32.

19. Weinberg E D. Roles of iron in neoplasia. Promotion, prevention, and therapy, Biol Trace Elem Res, 34 (1992) 123.

20. Rajendran R, Vasudevan DM, Vijayakumar T.Serum levels of iron and proteins in oral submucous fibrosis (OSMF), Ann Dent, 49(1990)23. 


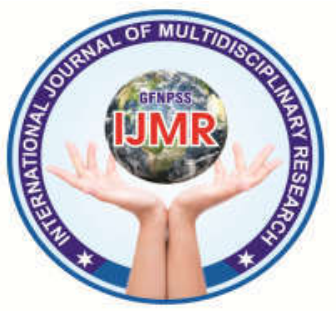

21. Jayadeep A, Raveendran Pillai K, a preliminary study Indian J Med Res, Kannan S, Nalinakumari KR, Mathew 98 (1993) 147.

B, Krishnan Nair M, Menon VP.

23. Maguire JJ, Kellogg EW 3d, Packer L. Serum levels of copper, zinc, iron and ceruplasmin in oral leukoplakia and squamous cell carcinoma, J Exp Clin Cancer Res, 16(1997) 295.

22. Anuradha CD, Devi CS. Serum protein, ascorbic acid \& iron \& tissue collagen in oral Submucous fibrosisProtection against free radical formation by protein bound iron Toxicol Lett, 14(1982) 27.

24. Lapenna D, de Gioia S, Mezzetti A, Ciofani G, Consoli A, Marzio L, Cuccurullo F. Cigarette smoke, ferritin, and lipid peroxidation, Am J Respir Crit Care Med, 151 (1995) 431. 